\title{
Aspects of European Legal Harmonisation: When European Politicised Law Meets Freedom of Establishment and Vice Versa
}

\author{
Jean Mohamed ${ }^{*}$ \\ Freshfields Bruckhaus Deringer, Hamburg, Germany \\ jean.mohamed@hbu.de
}

Abstract

Keywords $\quad 412$

I. Prologue 412

1. The General «Sujet» of European Legal Harmonisation 412

2. The Microcosmic Reflection on the Field of Freedom of Establishment 413

3. Course of the Analysis 415

II. Driving European Forces $\quad 415$

1. European Commission 416

2. The Committee on Legal Affairs (JURI) 417

3. The Experts 417

4. The Advocates-General 418

5. The Member States $\quad 419$

6. Interim Conclusion $\quad 420$

III. Components for the Harmonisation of European Company Law and Freedom of $\begin{array}{ll}\text { Establishment } & 420\end{array}$

1. Art. 50(2) lit. g) TFEU in the Context of Competence Standards 421

2. Flood of Directives $\quad 422$

3. Regulations and Recommendations 423

4. Urgent Legal Acts and State Issues (COVID-19) 423

IV. The Special Role of the ECJ in Regulatory Questions of Mobility 424

1. Abstract Considerations 424

2. Scope of Jurisdiction of the ECJ 425

a) Stages Outline $\quad 426$

b) Critique and Perspective $\quad 428$

3. Could Only the ECJ Assume this Special European Role? 429

V. Brexit and Regulatory Opportunities 431

VI. Responses to the Structure of the ELH and the European Search for Legal Balance 433

1. Basic Components 433

2. Hyper-Europeanisation 435

3. Legal Doctrine or Case Law(?) 437

4. Expansion of the National Discourse through Key Player 439 VII. Coda

\footnotetext{
* Dr., Mag. iur., LL.M. (LSE), previously at London School of Economics and Political Science (LSE), and the Department of Corporate Law at the University of Hamburg. Many thanks to Floris De Witte (LSE) for rich discussion inputs on interaction and forces of the EU. All links were last retrieved on 1 December 2020.
} 


\section{Abstract}

The following article deals with questions of European Legal Harmonisation and takes an exemplary approach to an initial analysis of the field of freedom of establishment and its effects on European company law. This Europeanised field of law thus represents an inductive observation of the topic of harmonisation but it can also occasionally symbolise, pars pro toto, other harmonised legal areas. Regarding freedom of establishment, it should be shown that European harmonisation has been taking shape for many years and that new requirements are constantly being created for, and through diverse political key players. Here, some key players could be identified, the special role of the European Court of Justice could be emphasised; and topics of such Europeanisation could be briefly pursued. However, it will be shown that the monopoly position of this institution - not political in itself - is remarkable. Finally, full harmonisation is probably not yet on the way in terms of legal culture and is hardly feasible in practice. In part, however, we will also attempt to provide a general categorisation of the socio-legal as well as normative key aspects, and their consequences for the de facto European legal harmonisation. In an initial review, we also want to look at ways of improving the system.

\section{Keywords}

Harmonisation - Europeanisation - key player - freedom of establishment - company law - Role of the ECJ

\section{Prologue}

\section{The General «Sujet» of European Legal Harmonisation}

European integration and harmonisation in national law has many complexities that must be considered in historically diverse legal cultures. As always, the coin has two sides: There can be positive as well as negative effects. Law is not only a regulatory technique but also a cultural asset and the result of democratic decision-making processes. The European Union's efforts to promote market harmonisation, the realisation of the internal market, and the corresponding harmonisation movements help to view the law primarily from the perspective of positive unification. Of course, this has a long tradition that dates back several decades. Legal compliance and clarity, however, have a 
social and cultural function that extends beyond this, which must not be lost sight of and sacrificed to a one-dimensional approach. Supranational legal harmonisation must therefore keep a proper balance between uniform readjustment and established legal systems as well as the considerable increase in complexity for the practitioner. The forced creation of a European rule of law can thus relate to all areas of law, and therefore, generally represents an important topic for an analysis of the characteristic steps, techniques and history of harmonisation. ${ }^{1}$ However, the law in the classical sense can no longer be understood as a purely national area of law, whereby legal-political and economic considerations in particular are becoming increasingly crucial in the Europeanisation of the legal system. De facto, Europeanisation plays an immense role in politics, law, and practice. Thus, we are dealing here with a status quo that can be considered not only dogmatically but also in general and, first of all, from its factual existence. A consideration of the legal facts may, therefore, also contribute to a common frame of reference between possible benefits of harmonisation and the inevitable frictions resulting from interventions in national structures. Therefore, the following is about reflections in order to be able to place the topics of the doctrine in law. If politicised issues are occasionally addressed here as legal drivers, this paper will not refer to procedural questions of political law but rather to political-democratic and institutional aspects that actually move legal harmonisation.

\section{The Microcosmic Reflection on the Field of Freedom of Estab- lishment}

There are different methodical ways to gain insights into European legal harmonisation (ELH). One may, for example, distinguish between inductive and deductive procedures. In deductive methods, conclusions are drawn from the general to the particular. Thus, we could try to examine the fact and the essential developments of ELH in the form of premises; the results could then be reflected on individual fields of law. This would be quite a lot and difficult to accomplish in one article. It is also difficult to claim here that harmonisation has taken the same path in all areas of European law. Via the inductive path, we can in turn approach the general from an individual observation. Deeper structures, connections, and mechanisms should thus be made more easily visible in a field. However, legal harmonisation in field $x$ is not necessarily the same as in field $y$, and both fields of law could rather have

1 See, for example, the German monograph of Marcel Kau, Rechtsharmonisierung (Tübingen: Mohr Siebeck 2016), which deals with the European harmonisation. 
their own rules. For corporate law, it might be obvious to take out the European political freedom of establishment $(\mathrm{FoE})$ and its cross-relations to the so-adjusted corporate law for a single testing. In terms of content, this concerns the European freedom of movement and transformation of companies as well as influencing national regulation of corporate law through European Union (EU) rules (directives and regulations). It is therefore a matter of evaluating a specific field exclusively in the service of the European harmonisation movements. But what is the main reason why this field of law is chosen as reference to study ELH? It seems, therefore, that the FoE is particularly suitable as a testing ground, since a very broad wave of harmonisation can be presented with economically and politically significant effects on the one hand and the diverse participation of actors - especially the European Court of Justice (ECJ) - on the other (see II.). This considerable legal diversity of European corporate law should be beneficial for evaluating ELH within that area.

Nevertheless, what are the respective areas of law in the European politicised FoE, and how did the line of development take place in terms of European legal tools and judicature?2 Can synergy effects for the single national rights be achieved through Europeanisation? All of this may have considerable consequences for the Europeanisation of the legal doctrine. Last but not least, Brexit can have considerable consequences for the British legal system (see V.). Here, so to speak, the issue of re-harmonisation for the United Kingdom arises. At the same time, the future of both, the once harmonised European law pre-Brexit and the political and legal influence in harmonisation areas post-Brexit are at stake. However, as already indicated, the practical role and work of European actors within ELH can also have a particularly strong impact on one field; for example, a long period of jurisdiction can have a particular influence on ELH. Therefore, of particular significance for our analyses is the cascade of decisions of the ECJ on the crossborder transfer of companies in light of Arts 54 and 49 of the Treaty on the Functioning of the European Union (TFEU). That cascade could contain a historical stringency and thus also a political agenda. After all, the FoE of companies should serve the very purpose of enabling an optimal allocation of economic resources on the territory of the EU.

From a general European perspective, these are questions that can arise in any legal area, and neither begin nor end in company law. Any harmonisation of law, for example in private law, is subject to the area of conflict described

2 Due to the various limitations of an essay, I would like to look at the actual development of the field and in particular at the regulatory components and the ECJ case law on corporate mobility (see III. and IV.). 
above and involves coherence issues in national private law. ${ }^{3}$ In addition, the institutional, personal, and political decision-making chain is also a fundamental issue in other areas of private law harmonisation. Overall, politicians are grappling with the enormous challenges facing society. Would a move to a more harmonised law system go any way towards solving the issues of the time? In order to pursue the idea of integration and harmonisation in casu, company law and FoE will be highlighted as an example and examined from a European constitutional perspective. The above topics serve as parameters and are intended to show that the idea of harmonisation - at least in this area of law - is to some extent excessive and creates a union law through the back door that is essentially guided by the actually non-political body, namely the ECJ.

\section{Course of the Analysis}

In the following, a key player categorisation (II.) will be used in a sociolegal ${ }^{4}$ sense to show that not only anonymous opinion-formers are involved in the harmonisation of law but also individual and important voices from EU institutions and the individual states, using company law as an example. It follows a technical description of the level of harmonisation under EU law on a, so to say, mini-empirical level (III.). We then turn to the major key player - the ECJ (IV.) - and critically present its role in the light of the case law on freedom of establishment. After an overview of the current Brexit and the ex-post legal harmonisation period (V.), at the final chapter (VI.) follows a critical, systematic, and evaluative review of the effects of such harmonisation in national law, and of possible other approaches.

\section{Driving European Forces}

It is obvious as it often happens in studies that the researcher gets straight down to the case law of the ECJ and analyses the forms of FoE over several

\footnotetext{
3 See, in general, on European private law approximation Jürgen Basedow, 'Das BGB im künftigen europäischen Privatrecht: Der hybride Kodex', AcP 200 (2000), 445-492; Jens Koch, 'Die Einheit der nationalen Rechtsordnung und die europäische Privatrechtsangleichung', JZ 61 (2006), 277-284; Thomas Pfeiffer, 'Methodik der Privatrechtsangleichung in der EU', AcP 208 (2008), 227-247.

4 For a modern comparative understanding of socio-legal Studies: Annelise Riles, 'Comparative Law and Socio-Legal Studies' in: Mathias Reimann and Reinhard Zimmermann (eds), The Oxford Handbook of Comparative Law (2nd edn, Oxford: Oxford University Press 2019), 773-811; trendsetting Pierre Bourdieu, 'La Force du Droit/The Force of Law: Towards a Sociology of the Juridical Field', Hastings L. J. 38 (1987), 805-853.
} 
decades. Therefore, the ECJ undoubtedly has to be accepted as one of the key players ${ }^{5}$ in this area. Yet there is considerable dispute over the line of jurisdiction itself, even after more than 30 years since the first substantial decision given in the Daily Mail6 case. Nevertheless, such a key playermonopolisation does not seem sufficient in view of the various bodies involved and possibilities for the Europeanisation and politicisation of law; rather, it should be shown here that the driving forces for ELH are more widely dispersed. In a structure as complex as the EU, it would also be astonishing if many more people and institutions were not considered.

\section{European Commission}

As the "engine" and the control center, the Commission is responsible for drawing up proposals for new legislation and also assumes responsibility for these. Within the organisational structure of the Commission (see in particular Art. 17(6) of the Treaty on European Union [TEU]), the following key personnel players can currently be highlighted for entrepreneurial issues:

Paolo Gentiloni (Italy): Economic and Financial Affairs, Taxation, and Customs; and

Theorry Breton (France): Internal Market, Industry, Entrepreneurship, and SMEs.

At least in their political management, they deal (in)directly with topics relating to corporate and capital market law. However, the organisation of the Commission goes much further and in practice we have to go down one level and name the policy-related Directorates-General set up by the Commission, each of which is also headed by a Director-General. ${ }^{7}$

Although the citizens of each Member State are obliged to carry out their duties in complete independence, solely in the general interests of the Union (Art. 17 TEU), it is not far-fetched to think that certain national prior knowledge and developments are also taken into the European work of these members. It should also be noted that the Commission's planning compe-

5 From an institutional perspective, the literature on company law or FoE deals almost exclusively with the ECJ and its numerous decisions. Recently, however, Holger Fleischer introduced the legal notables at national level, for corporate law, in his paper titled 'Gesellschaftsrechts-Honoratioren: Schlüsselfiguren im Gesellschaftsrecht und ihr diskursives Zusammenwirken', NZG 24 (2019), 921-930; see also Hans-Ueli Vogt, Holger Fleischer and Susanne Kalss (eds), Protagonisten im Gesellschaftsrecht (Tübigen: Mohr Siebeck 2020).

6 ECJ, Daily Mail and General Trust, judgment of 27 September 1988, case no. C-81/87, ECLI:EU:C:1988:456.

7 In particular, the Directorates-General for 'GROW' and - with a special scientific value for Research and Innovation ('RTD'). 
tence also concerns the conception of the programs and thus a political structural task. According to this politicised postulate, legislative acts in European (company) law have been increasing in particular for years.

\section{The Committee on Legal Affairs (JURI)}

As is customary in parliaments, Members of the Euroean Parliament (MEPs) in the European Parliament are also divided into standing committees, ${ }^{8}$ in which the work of plenary sessions is prepared for specific areas. For example, the Committee on Legal Affairs (JURI) is responsible for, inter alia, legislation in the field of commercial law and should ensure that Union law is codified as simply as possible. With the preparation of legislative proposals and the organisation of hearings with experts, the bar for the legal significance of JURI is very high. Since the Member States are also represented by members in the committees, ${ }^{9}$ one could mention the aforementioned problem of the nationally preferred view - and here in the concrete expert discourse although with 25 members (currently 2019-2024) ${ }^{10}$ this national aspect spreads further than with the respective individual key players in the European Commission. Nevertheless, with five German members (two of whom are Vice-Chairs) and five French members at present, an increased influence of at least these two nations should be possible in the committee meetings.

\section{The Experts}

The respective experts have a certain shadowy existence in the public perception. It goes without saying that the European legislative and initiative procedure also draws on a certain amount of external expertise. However, where do the experts come from and what results can be seen for the implementation of the legal acts? A detailed study with a breakdown of the Member State nationality of experts could at least be a political-historical

8 Cf. to the sub-organs of the committees already from the German commentary literature Winfried Kluth in: Christian Calliess and Matthias Ruffert (eds), EUV/AEUV (5th edn, Munich: C. H. Beck 2016), TEU, Art. 14 paras 33 et seq.; Sven Hölscheidt in: Eberhard Grabitz, Meinhard Hilf and Martin Nettesheim (eds), Das Recht der Europäischen Union (67th edn, Munich: C. H. Beck 2019), TEU, Art. 14 paras 113 et seq.; Christian Kraus, Mitgliedstaatliche Repräsentanz in den ständigen Ausschüssen des Europäischen Parlaments (Bern: Peter Lang 2016).

9 The composition of the committees shall, as far as possible, reflect the composition of Parliament, see in detail Art. 183 seq. of the European Parliament Rules.

10 See JURI <https://www.europarl.europa.eu/>. 
analysis in the future. Looking back at the historical developments in law over recent years, it becomes apparent that all steps in European legislation were preceded by impressive reports ${ }^{11}$ written by (independent) experts. ${ }^{12}$ Moreover, core companies ${ }^{13}$ from the economy are also not left out of the expert opinions. In any case, the EU can thus look at and reform practical law from a very broad spectrum. This opportunity has and will be used, as can already be stated here.

Naturally, such studies or even hearings of experts before the Commission have a significant impact on the legislative process. Even the pre-selection of experts will be well thought out politically. Although the appraisal focuses on questions at the European macro level, it is unsurprising that the experts are particularly sympathetic to solutions of their respective national law, given that they know these national solutions or helped to develop them in particular. Nevertheless, such an actively-promoted background by the EU is an important component in order to take different nations seriously. In the future, however, it would be interesting to observe empirically how many experts with their views argue against their own national legal solution and how many want to have their own national solution exported to Europe. One could think that the latter would prevail.

\section{The Advocates-General}

The institution of the Advocate General (see Art. 252 TFEU) - which is mainly based on the French model $-^{14}$ is to be given the main task ${ }^{15}$ of

11 Recent examples are from German professor Jessica Schmidt (Bayreuth), upon request of the JURI committee of the EP (June 2016) for 'Cross-border Mergers and Divisions, Transfers of Seat: Is there a Need to Legislate?’ DOI: 10.2861/355250, available at <https://op.europa.eu/ $>$, or the extensive public consultation <https://ec.europa.eu/>, which allows national experts from all Member States to comment on individual aspects of a uniform EU Company Law.

12 This is confirmed by Rüdiger Veil in: Rüdiger Veil (ed.), European Capital Markets Law (2nd edn, Oxford: Hart Publishing 2017), $\ 1$ recital 48 already for European capital markets law.

13 As an example, a study by consultancy $E Y$ should be mentioned here <https://ec. europa.eu/> (topic of European cross-border operations).

14 «Commissaire du gouvernement», for details and similar institutions see Takis Tridimas, 'The Role of the Advocate General in the Development of Community Law: Some Reflections', CML Rev. 34 (1997), 1349-1387. More about the Advocate General in France and the ECJ: Mitchel de S.-O.-l'E. Lasser, Judicial Deliberations. A Comparative Analysis of Transparency and Legitimacy (Oxford: Oxford University Press 2010), Ch. 6 and 7.

15 See Francis G. Jacobs, 'Advocates General and Judges in the European Court of Justice: Some Personal Reflections' in: Mads Andenas and Duncan Fairgrieve (eds), Judicial Review in International Perspective, Liber Amicorum in Honour of Lord Slynn of Hadley (The Hague: Kluwer 2000), 17-28 (19-20). 
drawing up preparatory opinions, i.e. opinions that are not binding on the ECJ, by the Advocates-General, whose purpose is to support the ECJ in its decision-making. The importance of the written opinion for the understanding of the decisions can hardly be overestimated. ${ }^{16}$ Accordingly, it can be observed that the ECJ has recently referred to the opinions much more frequently and extensively than in the past. ${ }^{17} \mathrm{~A}$ more recent example from FoE can be found in the previously exactly contradictory and 67-paragraphsstrong opinion of the German Advocate General Juliane Kokott in the Polbud case (see IV. 2.). ${ }^{18}$ After all, the fact that the Advocates-General critically examine the case law and the (national) literature opinions of the complex (company) law within the framework of their expert opinions finally leads to a certain feedback of the final opinion on case law and doctrine and thus a stronger coherence and transparency of case law as a whole. ${ }^{19}$

\section{The Member States}

The role of the Member States in the European legislative process has already been explored from various angles in the literature, including that of the Council, which is intended to represent the interests of the Member States. ${ }^{20}$ Now it may be argued that Member States always have an overarching key player role in the EU and therefore do not need to be mentioned separately. However, we should not only mention the repeatedly propagated competition between legal forms, which is the driving force but also the brake of any attempt at European harmonisation of (company) law. Both abstractly and concretely, corporate law approaches can be very different. Some European projects may also fail given that Member States prefer to seek

16 Noreen Burrows and Rosa Greaves, The Advocate General and EC Law (Oxford: Oxford University Press 2007), para. 6 with further references.

17 See Bernhard W. Wegener, in: Calliess and Ruffert (eds) (n. 8), TFEU, Art. 252 para. 3, and in the past Tridimas (n. 14), 1357-1358.

18 ECJ, Polbud, Opinion of Advocate General of 4 May 2017, case no. C-106/16, ECLI: EU:C:2017:351.

19 Already Ulrich Karpenstein and Kathrin Dingemann, in: Grabitz, Hilf and Nettesheim (eds) (n. 8), TFEU, Art. 252, para. 16; Rudolf Streinz and Stefan Leible, 'Die Zukunft des Gerichtssystems der Europäischen Gemeinschaft - Reflexionen über Reflexionspapiere’, Europäisches Wirtschafts- und Steuerrecht 1 (2001), 1-11 (8).

20 About the internal function, e. g. Frank M. Häge, 'Who Decides in the Council of the European Union?’ J. Common Mkt. Stud. 46 (2008), 533-558. 
the way out in their national law rather than at the supranational level..21 The desire and aspect of market regulation in national law seem to be particularly popular at the Member State level. Therefore, the Member States themselves seem opposed to genuine European legal fields.

\section{Interim Conclusion}

It has been shown above that European organisational law provides a diverse variety of key players, which - in terms of ELH - are more than simply anonymous blocks of opinion that can be divided into "Parliament" or "Commission". Such a factual basis may become particularly important for the supranational context of legal harmonisation and may challenge one to consider not only the dogmatic peculiarities of European regulation. The diversity certainly brings with it a great deal of different know-how, but it also makes consensus-building a Herculean task.

\section{Components for the Harmonisation of European Company Law and Freedom of Establishment}

Why and how can European law regulate law at all, and - much more important - does it actually do so? Here again, it is worthwhile to look at the FoE and the regulatory possibilities as well as the history of harmonised company law, and to point out the status of ELH in a particular field. As we can note here, the portfolio of European legislative instruments has been and is being used enormously in the corporate field. The main topics covered by these regulations are: the approximation of company law to prevent a European race to the bottom, the improvement of shareholders' rights, the enabling of a cross-border transformation processes via directives, the creation of supranational legal forms, and the discussion of corporate mobility through Europe.

21 See the failed project of implementing a Societas Unius Personae (SUP) (Legal Observatory, European Parliament, 2014/0120(COD)); this project led to controversial discussions in the JURI committee but also in Germany (Negative resolution of Parliament, printed matter 18/4843). 


\section{Art. 50(2) lit. g) TFEU in the Context of Competence Standards}

If national companies are to have the right to operate throughout the Union and transfer their registered office from their foundation state to another Member State and continue their activities there, national law must be harmonised. Art. 50(2) lit. g) TFEU therefore empowers the Parliament, the Council, and the Commission to coordinate the safeguards which are required by Member States of companies or firms for protecting the interests of members and others to the necessary extent and to make such safeguards equivalent throughout the Union. ${ }^{22}$ The harmonisation of company law thus serves the primary law of FoE in accordance with Arts 49 and 54 TFEU. The provision therefore holds considerable practical significance. ${ }^{23}$

The original ambition of the European legislators was certainly to enable comprehensive coordination. This can easily be seen from the fact that, since 1968, directives have been given own numbering for European company law. ${ }^{24}$ Nevertheless, it must be articulated here that this article allows the approximation of Member States' rights concerning the right of establishment but not their unification. In order to broaden the freedom of design for creating new types of European legal entities, the EU is instead using Art. 352 TFEU as the basis of competence. ${ }^{25}$

In any event, Art. 50(2) lit. g) TFEU has the function of counteracting a distortion of competition through harmonisation, which may exist as a result of different provisions in the Member States. The European mandate to act in the legal rule thus guarantees a certain minimum degree of protection for the benefit of the members and any third parties concerned. In other words, a "race to the bottom" is to be counteracted, particularly with respect to national law systems. Conversely, the rule then always presupposes the existence of national minimum requirements for the protection of members and third parties. The provision cannot be applied when it comes to the

22 For the scope of this authorisation, see ECJ, Daibatsu, judgment of 4 December 1997, case no. C-97/96 ECR I-6843, paras 17 et seq.

23 Ulrich Forsthoff, in: Grabitz, Hilf and Nettesheim (eds) (n. 8), TFEU, Art. 50 para. 11; Stefan Korte, in: Calliess and Ruffert (eds) (n. 8), TFEU, Art. 50 para. 21, for example, have noticed this. Jürgen Tiedje (working for the European Commission) uses only 17 points in his commentary at Hans von der Groeben, Jürgen Schwarze and Armin Hatje (eds), Europäisches Recht (7th edn, Baden-Baden: Nomos 2015) for para. 1 and para. 2 except for lit. g), while the commentary for lit. g) includes around 95 points.

24 Some descriptions in literature are still based on this today, see critical Jürgen Tiedje, in: von der Groeben, Schwarze and Hatje (eds) (n. 23), para. 19.

25 See only ECJ, European Parliament v. Council, judgment of 2 May 2006, case no. C-436/ 03, ECLI:EU:C:2006:277, paras 38 et seq. (for Art. 308 EC). 
implementation of provisions, for which there are no national rules in the Member States. In other and general terms, the regulation in TFEU is not intended to create completely new national law. Only based on Art. 95 of the European Community (EC) (now Art. 114 TFEU) could and can completely new legal ideas be implemented. In the 1970 s, the view that the harmonisation of law was by no means limited to the mere realisation of FoE became widespread. Its real aim is to create equal conditions for companies from all Member States, ${ }^{26}$ and thus achieve full European harmonisation in this area of law. The same could also apply to other areas of law.

\section{Flood of Directives}

From a conceptual perspective, which is only outlined here, the approximation of laws through directives (Art. 288(3) TFEU) is characterised by a certain compromise: it is intended to harmonise the law while preserving national peculiarities - i.e. especially terminology and systematics - and legislative powers, which forms the basis of legislative approximation and therefore cooperation between European and national legislative bodies.

There is certainly no room for providing a complete list of all company directives ${ }^{27}$. It is interesting to note, however, that there was a first phase of harmonisation euphoria in the $1970 \mathrm{~s}$ to the mid-1980s (no less than six directives), while there was a phase of stagnation ${ }^{28}$ in the $1990 \mathrm{~s}$. In sum, the directives throughout the whole period are also a multitude of complex amending and linking directives. ${ }^{29}$

In view of the sudden number of legal acts, building blocks for legal harmonisation tend to become a complete foundation for national company law in the EU. In some cases, parliaments hardly lag behind with implementation.

26 Evidence in Elena Dubovitskaya, 'Niederlassungsfreiheit und Harmonisierung', Rechtstheorie 45 (2014), 517-552 (521-522).

27 Reference can be made to a list, available at <https://ec.europa.eu/> ("What the EU is Doing'). The European Commission writes that the purpose of the EU rules in this area are, among other things, to 'make business more efficient, competitive and sustainable in the long term' und to 'encourage businesses based in different EU countries to cooperate with each other'.

28 See in this regard Peter Behrens, 'Krisensymptome in der Gesellschaftsrechtsangleichung', in: Ulrich Immenga, Wernhard Möschel and Dieter Reuter (eds), Festschrift für ErnstJoachim Mestmäcker (Baden-Baden: Nomos 1996), 831-849; Klaus J. Hopt, 'Europäisches Gesellschaftsrecht - Krise und neue Anläufe', ZIP 3 (1998), 96-106.

29 Of particular importance for the freedom of establishment is the Directive (EU) 2017/ 1132 of the European Parliament and of the Council of 14 June 2017 relating to certain aspects of company law, OJ L 169/46, 30.6.2017. Nevertheless, the Commission had already submitted a far-reaching new Company Law Package (2018) with two new directives. 


\section{Regulations and Recommendations}

Using our legal example, the many directives are supplemented by five directly applicable regulations ${ }^{30}$ (Art. 288 (2) TFEU). Instead of 'harmonisation', the term 'new creation' of law would be more appropriate here (no implementation needed).

The European set of instruments is completed by means of (non-binding) recommendations pursuant to Art. 288 (5), 292 TFEU, which are used by the Commission. However, the recommendation is not only a plea for legal policy but - contrary to the wording of Art. 288 (5) TFEU - may have to be taken into account when interpreting national provisions: the ECJ attaches importance to recommendations for the interpretation of secondary EU legislation when these are concretised by recommendations. ${ }^{31}$ Remarkably, the Commission - as our key player - alone, can thus create guidelines for national courts on the interpretation of secondary legislation.

\section{Urgent Legal Acts and State Issues (COVID-19)}

The extremely difficult pandemic period in all areas due to the coronavirus certainly also brings with it a compelling need for legal adjustments in various areas. However, it is often not possible to comply with the EU's lengthy European legislative process and thus create either directives or directly applicable regulations for individual areas of law. For our testing field of European corporate law, this is reflected, for example, in the numerous purely national laws, to mitigate the consequences of the COVID-19 pandemic in corporate law and, in particular, in the participation in general meetings via electronic media (online general meeting) or the modification of insolvency law. ${ }^{32}$ Throughout Europe, such legal changes have been created ${ }^{33}$ but not on a European scale. In those areas of practical importance, and where rapid implementation is required, emergency legislation seems to be the more appropriate instrument compared to ELH.

30 Three of which serve to create supranational legal forms (corporate forms of SE, EEIG, and $S C E)$.

31 See only ECJ, Altair Chimica v. ENEL Distribuzione, judgment of 11 September 2013, case no. C-207/01, ECLI:EU:C:2003:451.

32 From a German perspective Federal Law Gazette 2020 I, 559, act on mitigating the consequences of the COVID-19-Pandemic in Civil, Insolvency, and Criminal Procedural Law.

33 See comparative law study on shareholder meetings by Dirk A. Zetzsche, Linn AnkerSørensen, Roberta Consiglio and Miko Yeboah-Smith, 'The COVID-19-Crisis and Company Law - Towards Virtual Shareholder Meetings', University of Luxembourg Faculty of Law, Economics \& Finance WPS 2020-007, <SSRN: https://ssrn.com/>. 


\section{The Special Role of the ECJ in Regulatory Questions of Mobility}

\section{Abstract Considerations}

As indicated above, the ECJ has always had a significant impact on harmonisation, EU-level policymaking, and national legal orders. The abstract question of the role of the ECJ in the political and institutional context of European law has occupied scholars for several years. ${ }^{34}$ Without proceeding into this level of theory in greater depth here, it can clearly be seen how the ECJ acts as a factor of integration for the Union. Indeed, the Court has always understood its mandate to uphold the law in a particularly dynamic way and has documented this understanding in an integrationfriendly interpretation of the Treaties, sometimes in bold legal developments.

This dynamic jurisdictional power is problematic insofar as it reaches the limits of judicial development of law or doctrine, which are also known to the individual Member States. However, despite the extensive jurisdiction of the ECJ, Art. 19 TEU contains a restrictive element among others. The Union judiciary has to exercise restraint in its judicial activity vis-à-vis the institutions whose task is to achieve the objectives of the Treaty by political means. In the following, it will be shown that there can be no question of such restraint regarding cross-border mobility. The ECJ has established itself as the key player par excellence in this respect and has set for the Member States - whether as principals or trustors - guidelines that result exclusively from the line of jurisdiction. While the wording of Arts 49 and 54 TFEU is very meager, the development has not happened by chance, but rather it is subject to a logical dogma (see below). Thus, the ECJ has even been able to intervene indirectly in legal policy matters and initiate substantial legislative procedures. Finally, it is remarkable that the conflict-oflaw rules have been turned upside down in all countries of civil law. An even stronger integrating role for the ECJ is thus hardly conceivable in practice.

34 On the one hand, it is discussed to what extent the agency theory known from business administration is applicable, see Mark A. Pollack, The Engines Of European Integration: Delegation, Agency and Agenda (Oxford: Oxford University Press 2013); Jonas Tallberg, 'Paths to Compliance: Enforcement, Management, and the European Union', Internal Organization 56 (2002), 609-643, while on the other a trusteeship model is debated, cf. Giandomenico Majone, 'The Logics of Delegation', European Union Politics 2 (2001), 103-122; Terry M. Moe, 'Political Institutions', Journal of Law, Economics, \& Organization 6 (1990), 213-253. 


\section{Scope of Jurisdiction of the ECJ}

The evaluations of the ECJ and its history on the thin wording of Arts 49 and 54 TFEU resemble the course of Franz Kafka's parable 'Before the law' and 'The Trial' on some points. It is said right at the beginning: 'Before the law sits a gatekeeper. To this gatekeeper comes a man from the country who asks to gain entry into the law.' Nevertheless at least the author of these lines here is not so certain about all evaluations of the gatekeeper from Luxembourg. However, in general terms of Europeanisation, the question of an applicable national law arises in all matters involving foreign links. This question is always answered according to the conflict-of-laws within the framework of European requirements. This was largely due to the question concerning whether the so-called 'real seat' 35 theory (civil law) was in any way impinged upon by the judgement of the ECJ. The real seat theory is a conflict-of-laws rule, determining the law applicable to companies (lex societatis) according to the head office or 'real seat', which was subscribed to by a number of EU Member States. ${ }^{36}$ Without delving into much detail here, this theory was applied in a detrimental way to mobility, making it de facto impossible for foreign companies to register in a Member State but conduct business exclusively in another Member State that followed the real seat theory. The concept of the 'incorporation theory' - which is particularly widespread in the Anglo-American ${ }^{37}$ states $^{38}$ - has a completely different impact. It made it possible to incorporate companies under domestic law and simultaneously subject them to the protection of this law at the place of actual business activity.

The jurisdictional tour of the ECJ therefore had to start logically - from a jurisdictional perspective - given that (any) European company may undertake a journey to another European state. In a series of judgements, the ECJ was able to create a European policy from 1999 (Centros) to 2017 (Polbud), which pushed back the theory preferred by civil law states and gradually developed European freedoms from immigration to emigration. A complete integration effect of European law could thus be created by the ECJ alone.

35 This theory was originally developed in the 19th century in Belgium (Arts 128, 129 of the Belgian law on commercial companies of 1873) and France (Cass. civ. 20.6.1870, p. 1870 I. 373).

36 See Wolf-Georg Ringe, 'Corporate Mobility in the European Union', ECFR 2 (2013), 230-267 (235 and n. 18).

37 For details, see Willis L. M. Reese, 'American Choice of Law', Am. J. Comp. L. 30 (1982), 135-146 (145 -146), or Robert A. Leflar, American Conflicts Law (New York: Lexis Pub 1968), 597.

38 The 'incorporation theory' also applies in some other European States such as the Netherlands (Art. 10:118 DCL) or Suisse (Art. 154 Swiss IPRG). 


\section{a) Stages Outline}

Instead of summarising (again) all of the complicated landmark decisions, this is an illustrative attempt - with some accompanying notes - to gain a broad overview:

(1) First stage of the mobility concept according to Centros, Überseering and Inspire Art, ${ }^{39}$
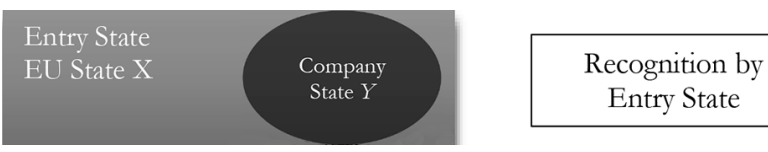

In the above triad of judgements, the ECJ has considered the consequences of applying the seat theory to companies effectively incorporated in another Member State of the European Union as incompatible with the FoE. Since then, companies established in the European Union have been able to transfer their effective administrative headquarters across borders to another Member State without losing the legal and party capacity they hold under the law of the founding state, provided that the founding state does not order the loss of legal capacity in this case.

(2) Second stage: departure while maintaining the foreign legal form according to Cartesio $^{40}($ ?);4

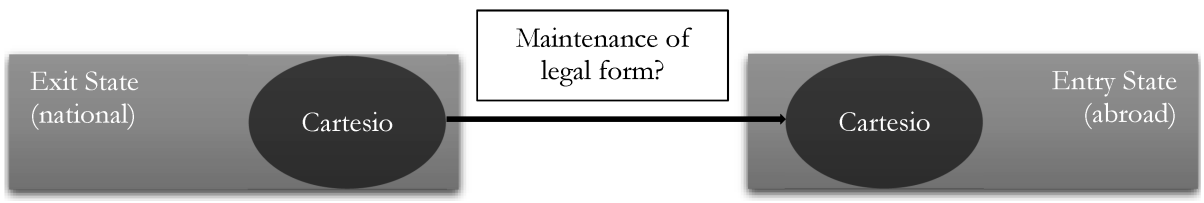

In Cartesio, the question was whether a company can migrate to another European country without changing its legal form. In Luxembourg, the ECJ

39 ECJ, Centros Ltd. v. Erhvervs- og Selskabsstyrelsen, judgment of 9 March 1999, case no. C-212/97, ECLI:EU:C:1999:126; ECJ, Überseering BV v. Nordic Construction Company Baumanagement $\mathrm{GmbH}$, judgment of 5 November 2002, case no. C-208/00, ECLI:EU:C:2002:632; ECJ, Kamer van Koophandel en Fabrieken voor Amsterdam v. Inspire Art Ltd., judgment of 30 September 2003, case no. C-167/01, ECLI:EU:C:2003:512. See further Anne Looijestijn-Clearie, 'Have the dikes collapsed?', European Business Organization Law Review 5 (2004), 389-418.

40 ECJ, Cartesio, jugment of 16 December 2008, case no. C-210/06, ECLI:EU:C:2008:723.

41 To compare it again with Franz Kafka: 'If it tempts you so much, try it in spite of my prohibition. But take note: I am powerful. And I am only the most lowly gatekeeper.', Before the Law, in: Franz Kafka, The Trial (novel: Der Process), Berlin: Verlag 'Die Schmiede' 1925. 
confirmed a previous principle established in the Daily Mail ${ }^{42}$ judgement, according to which a Member State may determine the conditions under which a company must be regarded as being further established under its national law. Only if the connection is positive, the company can benefit from the protection of FoE. The ECJ thus left it to the Member State and to the rules of that State to decide whether and if so, how the company could take its legal form abroad.

(3) Third stage: departure under conversion to a foreign legal entity (Ltd.) according to Vale, ${ }^{43}\left(\right.$ ?) ${ }^{44}$

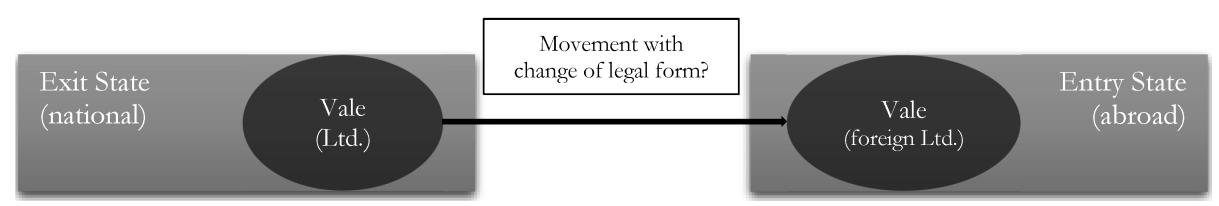

If the Member State does not allow the national legal form to be taken along, but the company nevertheless wishes to transfer its operational business abroad, the only way out is to change the legal form by transferring the registered office. Such a transfer of the registered office is only accompanied by a change of the legal form. This is still determined ${ }^{45}$ by the applicable law of the respective countries involved. In Vale, such a case was dealt with, but the host State did not provide for such a transfer of registered office by means of a change of the legal form of the company. However, the ECJ has implemented an obiter dictum according to Cartesio, and in this constellation, the $\mathrm{FoE}$ is applicable. The original company could be the carrier of the FoE. If the law of the host state provides a domestic conversion, such a conversion of a company governed by the law of another Member State into a domestic company by means of incorporation, cannot be refused. Unjustified discrimination of cross-border conversions is thus prohibited under EU law; since then, this would either have to be anchored in national law or, as in the case of Germany, applied in accordance with EU law. ${ }^{46}$

42 ECJ, The Queen v. H. M. Treasury and Commissioners of Inland Revenue, ex parte Daily Mail and General Trust plc., judgment of 27 September 1988, case no. C-81/87, ECLI:EU: C:1988:456.

43 ECJ, Vale, judgment of 12 July 2012, case no. C-378/10, ECLI:EU:C:2012:440; in detail Jesper L. Hansen, 'The Vale Decision and the Court's Case Law on the Nationality of Companies', ECFR 1 (2013), 1-17.

44 'But he recognizes now in the darkness an illumination which breaks inextinguishably out of the gateway to the law.' (see Kafka n. 41).

45 The Company Law Package (n. 29) will bring some changes based on a directive.

46 See for example Court of Appeal in Berlin, 21.3.2016, 22 W 64/15; Higher Regional Court of Nurnberg, 19.6.2013, 12 W 520/13; Higher Regional Court of Frankfurt, 3.1.2017, 20 W 88/15. 
However, it would also be conceivable to simply transfer the registered office without simultaneously transferring the administrative headquarters, exempli causa only for 'appearance'. Therefore finally ${ }^{47}$,

(4) fourth stage: departure under conversion to another legal form without the transfer of actual activity according to Polbud. ${ }^{48}$

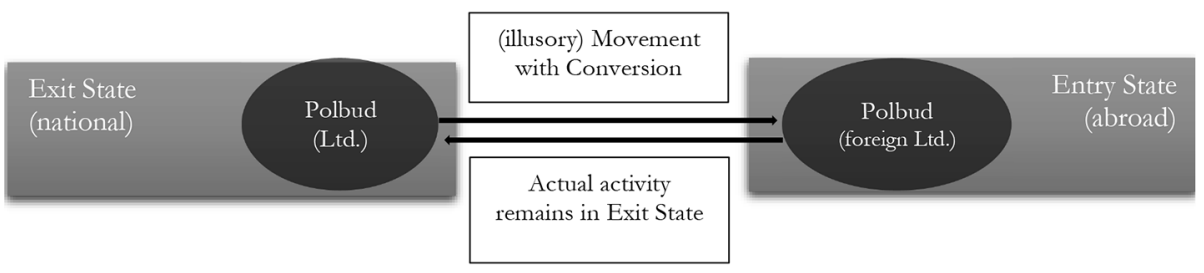

Once again, the issue was FoE, similar to the one at Vale, but with the crucial difference that the transfer of the registered office and conversion into a foreign company form was not accompanied by any change in the main focus of actual business activity in the other country.

The ECJ now recognises such a conversion below (4) 'in principle'. The use of the possibilities arising from the FoE does not constitute abuse per se.

\section{b) Critique and Perspective}

It will probably be possible to take the position that the European law is gaining momentum. However, the decision of the ECJ has attracted considerable criticism to date. ${ }^{49}$ In the constellation discussed in Polbud, it is more about 'appearance than substance'. However, it is only the actual exercise, or otherwise the recording of activities ensuring that the benefits of FoE (even more clearly in French «liberté d'établissement») are not just lured. ${ }^{50}$ This is

47 'What do you still want to know, then?' asks the gatekeeper. 'You are insatiable.' (see Kafka, n. 41).

48 ECJ, Polbud, judgment of 25 October 2017, case no. C-106/16, ECLI:EU:C:2017:804; see Stephan Rammeloo, 'Cross-border Company Migration in the EU: Transfer of Registered Office (conversion)', Maastricht J. Eur. \& Comp. L. 25 (2018), 87-107.

49 See Peter Kindler, 'Unternehmensmobilität nach "Polbud": Der grenzüberschreitende Formwechsel in Gestaltungspraxis und Rechtspolitik', NZG 1 (2018), 1-6; Ariel Mucha/Krzysztof Oplustil, 'Redefining the Freedom of Establishment under EU Law as the Freedom to Choose the Applicable Company Law', ECFR 2 (2018), 270-307 ('open another Pandora's box').

50 Instead of many from German literature Dirk A. Verse, 'Niederlassungsfreiheit und grenzüberschreitende Sitzverlegung - Zwischenbilanz nach "National Grid Indus" und "Vale" -', ZEuP 3 (2013), 458-495 (478-479); also recently critical: Eberhard Schollmeyer, 'Von der Niederlassungsfreiheit zur Rechtswahlfreiheit', ZGR 1 (2018), 186-201 (193); different Walter Bayer/Jessica Schmidt, 'Grenzüberschreitende Mobilität von Gesellschaften: Formwechsel durch isolierte Satzungssitzverlegung', ZIP 47 (2017), 2225-2234 (2229-2231). 
seen to be different in Luxembourg. Now there is a great danger that a national competition of the lax regulations will be set in motion. Companies might ask themselves why they should remain in national employee participation or, for example, not opting for a more favourable tax law (e.g. Liechtenstein instead of Germany)? Whether the cross-border admission of mailbox conversions in times of money laundering and heated discussions on tax havens is the proper sign for and from Member States, one may answer in a 'political' way for themselves. The difficulties with value judgement are also shown by a comparison with individual persons:

Imagine that a person with European citizenship $x$ (born and raised in $x$ ) wants to be released from this citizenship. And let us assume that the fictitious state $y$ knows the acquisition of an 'effective' citizenship without the need for a specific national 'bond' (wide open doors policy). Would we not want to allow such a meaningless sham change of nationality? The law on nationality allows such a change by all means (cf. Art. 18 German nationality act). Do we have to decide differently between natural and legal persons?

A mandatory distinguishing feature is not obvious, and thus the ECJ's political integration line is at least clearly in the direction of a 'European singular market'. However, according to the history of the ECJ on the right of FoE, it should not come to the point where it is said with Franz Kafka again: 'Here no one else can gain entry, since this entrance was assigned only to you. I'm going now to close it.'

Finally, it must also be remembered that the granting of choice of law as the key issue of national law (and corresponding economic policy considerations) has been answered in each case. The very different answers in the European Member States do not result in a rainbow in which everything ultimately comes together despite the difficult initial question. The creation of a rainbow through European rules is difficult to imagine.

\section{Could Only the ECJ Assume this Special European Role?}

What does the stocktaking of the wave of legal harmonisation with reference to the ECJ itself show us? If one takes Polbud and the subsequent legislative act, ${ }^{51}$ only about six months have passed between the case law and the proposal for a directive. The Commission also refers several times to the recent judgement in Polbud. The distribution of roles is described as follows:

51 See n. 29. 
'But the ECJ, being a judiciary organ, may not create any procedure [...] Therefore, the EU legislator needs to step in and provide for rules on [...] to create a dynamic and fair Single Market. ${ }^{52}$

The 'dynamic and fair Single Market' has been materially initiated and stimulated by the ECJ. The role of the European Commission and the Parliament then degenerates into that of the sole executor. The issue here could in fact have been tackled by the other European institutions over the decades, although the ECJ is the driving force behind it all. Such developments could also occur in other areas of law. Whoever mentions the ELH must therefore, at least for the purpose of our study, name an actor with the ECJ who is not formally involved in the legislative process. The path toward legal harmonisation can thus also be essentially shaped by the courts that, in turn, develop a certain momentum of its own from a democratic point of view.

Now one may claim that the wave of harmonisation of the EU and the ECJ is no longer as fundamental as it used to be years ago (e.g. introduction of a Societas Europaea). Of course, the ECJ only decides on what is presented to it, and there appears to be a lack outside ${ }^{53}$ the cross-border options. Nevertheless, it is remarkable that the ECJ line on the cross-border issue has been stringent over the years and could be judged in light of the scenarios. Within its judgements, the ECJ has also tried to continue the series logically. This presupposes a political power that the ECJ holds independently of democratic feedback.

Practice dictated the cases and the ECJ gave its verdict at the European meta-level. Nevertheless, in the national practice of the Member States, a certain degree of uncertainty becomes apparent each time concerning how to proceed nationally in conformity with European law. This raises the question as to whether the ECJ's special role here should not also be accompanied by formal legislative assistance, which is docked in the judgements themselves. Conversely, there is the question regarding why in quite other important and highly politicised issues, which may also have a directive reference (Art. 267 lit. b) TFEU), the ECJ does not receive any submissions at all and, as a consequence, cannot present its broader European perspective. Here the Member States, national courts and perhaps even lawyers may not want to work with European law when drafting their pleadings, preferring instead the familiar ground of national doctrine and methodology. Various core questions of law dealing with politics and legal-culture may not be left to the

52 COM (2018) 241 final, 2018/0114 (COD).

53 At least, the important ECJ, Erzberger v. TUI AG, judgment of 18.7.2017, case no. C566/16, ECLI:EU:C:2017:562, was on an interface between corporate law and labour law. 
ECJ after all, whereas in the case of European mobility it is too obvious that only the ECJ can assume the special role and that there is no way around it. Politically speaking, the same is certainly true for the free movement of individual persons.

\section{Brexit and Regulatory Opportunities}

The exit of the United Kingdom from the European Union does not stop at any legal field. In any case, the list of questions and topics is long, e. g. will the common law still shape the future of European law? Who will benefit from the new regulatory European competition? Two main areas can be addressed. The first is the question of the United Kingdom's political and creative role in the legal harmonisation of the legal instruments on FoE and corporate law which have been in place for years. How will the no longer directly possible influence within European legislation affect these areas when these areas have been affected by the know-how of the United Kingdom for years? Having said that it is certainly also a question of the United Kingdom's own role and the rules still in force from the ELH through legal acts or ECJ case law. If the cascade of ECJ rulings no longer have direct validity (Art. 50 TEU), this opens up a completely new scope for action; the same applies, for example, to regulations or directives that were once in force but have already been nationally harmonised. This state of affairs, if it occurs, has, so to speak, two sides of the same coin: How will the ELH itself be affected for our test field vis-à-vis the position of the United Kingdom itself? Since the issue is a fundamental one in itself, we can and will only outline a few ideas here (meanwhile, The EU-UK Trade and Cooperation Agreement formally entered into force on 1 May 2021).

ELH can also be compared to the narrative of competition of the legislators. ${ }^{54}$ From today's perspective, the Europe-wide competition of legislators - e. g. the competition for the most attractive legal dress for companies in the global market - has already fully erupted. After the United Kingdom - with

54 Such competition in European company law has already been discussed by David Charny, 'Competition among Jurisdictions in Formulating Corporate Law Rules: An American Perspective on the "Race to the Bottom" in the European Communities', Harv. Int. L. J. 32 (1991), 423-456; Lars Klöhn, 'Supranationale Rechtsformen und vertikaler Wettbewerb der Gesetzgeber im europäischen Gesellschaftsrecht: Plädoyer für ein marktimitierendes Rechtsformangebot der EU', RabelsZ 76 (2012), 276-315; Friedrich Kübler, 'Rechtsbildung durch Gesetzgebungswettbewerb? Überlegungen zur Angleichung und Entwicklung des Gesellschaftsrechts in der Europäischen Gemeinschaft', KritVj 77 (1994), 79-89; Hanno Merkt, 'Das Europäische Gesellschaftsrecht und die Idee des "Wettbewerbs der Gesetzgeber"', RabelsZ 59 (1995), 545-568. 
the peculiarities of its common law - has always been able to take a step forward as a role model for years and as a counterpart to the familiar continental legal systems, it now seems to be taking two steps backwards. In the future, it will no longer be able to shape horizontal competition between national legal systems in a European political manner. A level playing field created by directives will no longer be able to have Britain's signature directly. This not only threatens a loss of legal culture ${ }^{55}$ for the whole. There is a threat of stagnation of a previous global player, which affects not only the supranational system of legal forms but also especially the entire horizontal competition. All of the above phases of harmonisation through legislation or through the ECJ were, to a certain extent, also based on innovative fundamental ideas and structures. Now, the need and desire for such innovation will of course not be reduced by the entry of the Brexit and the loss of a seat at the EU table. In other words, the United Kingdom can of course continue to contribute its expertise on ELH issues, for example, in the legal area we are discussing here. If it is the United Kingdom that makes the impact, the EU is unlikely to say 'no' to harmonisation advice, even in the face of Brexit. Conversely, the United Kingdom will also do well to maintain the level playing field, including its ideas for shaping the future. There is no doubt, however, that it will be more difficult to implement legal aspects and that there would no longer be a political voice at this stage. The negotiating position therefore shifts towards an advisory function. After all, the ECJ's position, which is particularly strong on the (corporate and economic) issues discussed here, will be almost impossible to influence. It will therefore hardly be possible to lend a hand in this catalyst of legal development. In this respect, Brexit therefore also offers opportunities for Member States to become new role models or global players.

Otherwise, it may also lead to the United Kingdom freeing itself from some European legacy burdens that it has only taken on because of the obligation to transpose directives, thereby upsetting its own concept. An anecdotal example is the implementation of the directive on takeover bids 2004/25/EC, which essentially incorporated many points of the English Takeover Code by the then self-regulating Takeover Panel. ${ }^{56}$ As happens in a democracy, however, a

55 There is a very rich body of literature on the significance of legal culture, which deals with various areas of culture and law, see, for example, in detail Clifford Geertz, 'Local Knowledge: Fact and Law in Comparative Perspective' in: Clifford Geertz (ed.), Local Knowledge, (London: Fontana Press 1983), 167; Clifford Geertz, 'Thick Description: Towards an Interpretive Theory of Culture' in: Clifford Geertz, The Interpretation of Cultures, (New York: Basic Books 1973), 3; William Ewald, 'The Jurisprudential Approach to Comparative Law: A Field Guide to "Rats"', Am. J. Comp. L. 46 (1998), 701-707; in the context of the legal transplant discussion, for instance Gunther Teubner, 'Legal Irritants', M. L. R. 61 (1998), 11-32.

56 See details under <https://www.thetakeoverpanel.org.uk/>. 
number of other adjustments were made which the English Takeover Regulation had not previously known: e.g. the new General Principles ${ }^{57}$ or the classification of the Takeover Panel as a public - and not only private selfregulatory - supervisory authority ${ }^{58}$. For such harmonisation constraints and defragmentation of the self-created law, the United Kingdom could therefore also thankfully accept the Brexit and change it back. Sometimes this may seem advantageous for national doctrine, sometimes it may be nostalgic without great multipurpose. In this respect, Brexit offers an opportunity again - for the United Kingdom in the revolution of its own dogmatics anyway. Uniformity is, however, to a not inconsiderable extent part of the legal history of FoE (see IV. 2. a). Moreover, as said before, the ECJ will no longer be able to play a strong role, which leaves the United Kingdom more room for manoeuvre. The nationally and politically rather unpopular guidelines of the ECJ could therefore soon be shelved. This in turn could have repercussions for the EU and the jurisdiction of the ECJ itself, since new topics and approaches of a soon to be third country would be created in relation to areas of EU law which had already been uniformly harmonised and which the United Kingdom had once already supported. New momentum might be created.

\section{Responses to the Structure of the ELH and the European Search for Legal Balance}

In the following, we will finally turn to three thematic subdivisions, on the basis of which the course of the abovementioned ELH can be critically discussed within and especially by the EU. Within the tight corset of an essay, it is initially only a matter of sensitising people to a few areas. For the most part, we want to continue to limit our considerations to the microcosm of FoE and harmonised company law.

\section{Basic Components}

Even if a uniformity of complex topics such as the ELH here is difficult to achieve, we could reveal at least three basic factors here:

We are dealing with a wide range of key players who have left their mark on the ELH, including a particularly strong role for the ECJ in matters of

\footnotetext{
57 See David Kershaw, Principles of Takeover Regulation (Oxford: Oxford University Press 2016), 4.50 et seq.

58 See already Kershaw (n. 57), 4.17 et seq.
} 
FoE. European competence for legislative powers obviously provides a basis for ELH, which is also used in a variety of ways (see III.). Finally, the national legal understanding (NLU) plays an important role since the harmonisation effects must ultimately find their way into the national legal doctrine and practical work.

However, special appeal may have been made to research-oriented European legal experts to continue thinking about such key factors of ELH. In other words, it can only be a cautious approach to present some key factors from a narrow socio-legal perspective and the history of the ELH. These components can probably be applied to other areas as well. European competence or the NLU should also play a role in framing questions concerning services, the internal market, or capital movements. At the same time, the ECJ also plays a special role in other areas. One can think of the application of the free movement of workers to professional athletes..$^{59}$ Conversely, however, such a logical cascade of case law cannot be presented here. Yet key players will also exist on two levels. On the one hand, there are likely to be key players in European law in general, although these are probably at the highest institutional level. On the other hand, as presented here, there will also be driving forces in particular (see II.), and there may be particular sociological aspects depending on the field of law. What follows can, on the one hand, be of general importance for other reference areas, but, on the other, is partly limited to the field of FoE. If required, this will be pointed out.

In view of the special line of development on the FoE, the ECJ takes a prominent position. The ECJ had a special focus, in particular on company law regarding mobility issues, although in the combinatorial field each of the components must generally be considered. The main position of the ECJ, therefore, only affects questions of cross-border mobility, whereas for other areas of law the ECJ could be given even more weight. This means that, at least for this legal test field, we want to emphasise that even in the field of key players there is a separate ranking in which the ECJ stands out. However, since the ECJ is not a directly composed democratic body, this may be somewhat biased in terms of state theory. As mentioned, the weighting of the key players and the ECJ itself for all other thematic areas of EU law can hardly be carried out here. Nevertheless, there seems to be a trend in literature to focus on and to emphasise the high-level judicial architecture of

59 See already ECJ, Union royale belge des sociétés de football association ASBL v. JeanMarc Bosman, Royal club liégeois SA v. Jean-Marc Bosman and others and Union des associations européennes de football (UEFA) v. Jean-Marc Bosman, judgment of 15 December 1995, case no. C-415/93, ECLI:EU:C:1995:463; ECJ, Olympique Lyonnais SASP v. Olivier Bernard und Newcastle UFC, judgment of 16 March 2010, case no. C-325/08, ECLI:EU:C:2010:143. 
the ECJ. ${ }^{60}$ The effect of its integrative case-law in relation to the doctrinal peculiarities of each country will be discussed in VI. 3 .

What is not answered here is the factual question of whether NLU may or should occasionally break up all of this in its favour. In other words, the question may be whether NLU can claim a very specific process for legal factor $x$, whereas a national group resistance for legal factor $y$ does not exist in this way. Such key components can only represent a type of socio-legal idea of a system of equations for ELH and the structural form of interaction. Therefore, we want to take a critical look at the individual elements.

\section{Hyper-Europeanisation}

As is often the case, there are pros and cons in Europeanisation effects and approaches. What would it be like as a thought experiment if all the above were to result in a full harmonisation? Let us take a look at the integration efforts of the ECJ, for example. The great merit of the ECJ primarily lies in the fact that it has advanced and virtually revolutionised the harmonisation of law phenomenally through its broadly liberal case law. The major beneficiary seems to be at least the EU's legal practitioner: standardisation brings security, simplification, and, in particular, speed and cost benefits. However, this is only possible if the decisions are based on a uniform view and are logically supported by themselves. In view of the ECJ's line of case law outlined here, one can see such stringency regarding the European mobility of companies. Nonetheless, the value decisions behind this line are highly sensitive and trigger some controversy ${ }^{61}$ here and there. The other point of criticism is that

60 See, for example, on European private law Jürgen Basedow, 'Der Europäische Gerichtshof und das Privatrecht über Unsicherheiten, Allgemeine Grundsätze und die europäische Justizarchitektur', AcP 210 (2010), 157-195; on the impact on environmental law recently Martin Kment (ed.), Der Einfluss des Europäischen Gerichtshofs auf das Umwelt- und Infrastrukturrecht (Tübingen: Mohr Siebeck 2020); on the methodology of the ECJ in copyright law, for example Verena Roder, Die Methodik des EuGH im Urbeberrecht (Tübingen: Mohr Siebeck 2016); on the particular aspect of the democratic legitimation of the ECJ: Tobias Mähner, Der Europäische Gerichtshof als Gericht (Berlin: Duncker \& Humblot 2005); the ECJ as an engine of integration in sociological terms studied by Martin Höpner, 'Der Europäische Gerichtshof als Motor der Integration: Eine akteursbezogene Erklärung', Berliner Journal für Soziologie 21 (2011), 203-229; also Antoine Vauchez, 'The Force of a Weak Field', International Political Sociology 2 (2008), 128-144; recently with further reference to the ECJ as the main actor Ferdinand Kirchhof, 'Der Richter als Kontrolleur, Akteur und Garant der Rechtsordnung', NJW 21 (2020), 1492-1497 (1495).

61 See IV. 2. a), but also recently Martin Gelter/Lécia Vicente, 'Abuse of Companies through Choice of Incorporations?', ecgi paper No. 473/2019: '[...] it seems that the CJEU's case law has left us with a vision without a need for a doctrine of abuse.' 
law is not a complex that has arisen everywhere in the same way, has always made the same evaluations, has the same systematic approach, etc. Cultural differences are anchored in many areas of law. Some differences are minor, while some are fundamental62 (see above seat theory versus incorporation theory). In some cases, harmonisation is not carried out in such a way as to take the middle course, but rather the concept is fully accepted. It goes without saying that there will then be critical voices against this. Incidentally, the systematisation of the national law is hardly legally well worth a look.63 Only those who remain up to date at all times will be able to keep the overview. The legal practitioner - in particular the lawyer - is faced with a major realisation: what the practitioner once learned as his/her national law is disappearing little by little. All of this should not be a lament about worse times and that everything was better in good old days; rather it is an impression of how the weights shift. Of course, this new beginning has a magic of its own. ${ }^{64}$ Incidentally, company law as an example is still predominantly shaped by national paradigms. After all, legal systems developed over decades and centuries are difficult to pull down without shaking their foundations. However, it is quite clear that in terms of content, it is necessary to modernise from time to time, whereas over-Europeanisation of national laws repeatedly raises the question of whether legal standardisation should not be planned directly as a major project of uniform laws. This will certainly be startling for some people! However, this would no longer be an approximation within the meaning of Art. 50 TFEU (see III. 1.); and the EU has not provided itself with the competence in this standard. A full harmonisation would therefore call for special legitimation; although in some respects it is, nevertheless, particularly encouraged by the most 'neutral' institution in certain areas. Conversely, less harmonisation could be tested in the pure politicisation of the legal discussion and greater national freedoms in implementation, namely soft or principle-based directives. In other words, the emphasis would be on more political, even media-effective, 'comply and explain' and, at the same time, more national implementation power.

Nevertheless, even if the practical advantages and simplifications of an ELH in areas that are not highly sensitive and culturally deep-rooted would

62 On culturally loose or deeply embedded ties already Teubner (n. 55), 11 (17-18), and Otto Kahn-Freund, 'On Uses and Misuses of Comparative Law', M. L. R. 37 (1977), 1-27.

63 An example might be the German Stock Corporation Act, in which 7 letter paragraphs with several paragraphs have been introduced following the recent implementation of a Directive (\$S $67 \mathrm{a}-67 \mathrm{f})$.

64 See, for example, on an understanding of transnational law 'beyond the state', in which European states also influence themselves in their respective roles in the EU, Ralf Michaels, 'Transnationalizing Comparative Law', MJ 23 (2016), 352-358 (355-356). 
have some merit, this topic is still open to questions. What are those areas that are so deeply culturally anchored that they can hardly be standardised, and where the ELH cannot be effective? Are these issues related to legal doctrine (see VI. 3.)? In addition, can there be such hyper-Europeanisation in the case of more economic topics such as European company law? These basic approaches alone complicate the idea of a full wave of harmonisation. However, if one ignores the question of whether a uniform European company law would be desirable at all, doubts arise in view of the resistance from many national groups and the variety of national legal rules as to whether such standardisation would be possible. The space of discourse has certainly become much larger and more diffuse, and much has changed due to the influence of the European legislators on matters of harmonisation. However, the more complex the field of law is, the more difficult it is to reach a consensus in terms of content, personnel, and institutions. For decades, it was still possible to find common ground on the mobility issues presented here in the context of FoE, but even these considerations have not all been received with open arms at the national level (see IV. 2.). The situation is even more complicated when it comes to regulations, guidelines, and implementation. The creation of a single rulebook ${ }^{65}$ is, therefore, unlikely to be the real issue; rather the focus would be on a balance between European and national requirements. In fact, it is currently more a question of whether the instruments of regulations and directives are used in a balanced manner. Incidentally, in view of some legal facts outlined here, Europeanisation seems to have already taken place largely and is continuing to do so in this area. This is where the critical discussions and evaluations should occur in the future and perhaps, as mentioned above, a reflection on softer regulations, more normative freedom and fewer mandatory requirements (principle-based).

\section{Legal Doctrine or Case Law(?)}

We have already mentioned cultural particularities in doctrine here. A particularly comprehensive ELH could have the consequence that one of the traditional strengths of German-language legal academia - doctrine and methodology $y^{66}$ - might come under pressure. However, it has long been

65 In European Financial Regulation, this is discussed in particular for the creation of a single rulebook by the supervisory authority ESMA (Paris), see Niamh Moloney, The Age of ESMA (Oxford: Hart 2018), Ch. IV.

66 On Germany, see Reinhard Zimmermann, 'Juristische Methodenlehre in Deutschland', RabelsZ 83 (2019), 241-287. 
clear that legal dogmatics is not a special path taken by just a few EU Member States but rather a path taken by jurisprudence and practice in the Union law itself. ${ }^{67}$ A proper European methodology seems, however, to be still in the process of being developed to support some transnational methodological concepts. ${ }^{68}$ Nowadays and due to specific fields of European private law, a phase of rather small-scale dogmatic ordering and structuring may well be in the foreground. A key role could be played here by the structural principles of unity and coherence, which in turn could refer to a systemic approach. However, EU law needs a toolbox for the lawyer to construct and analyse the legal material.69 The question is whether this approach truly exists in all areas of law. Here, an example was given of how a European case law approach ultimately dictates the disciplinary irrelevance of national jurisprudence and dogmatics and how social reality is created by European case law. Thus, when we look at the ELH, we are following, on a theoretical basis, a judicial tool rather than a methodological path. Such a shift in methodology may be possible in practice, but it is already questionable in democracy theory whether such an approach should and may replace legal doctrine in the EU. In other words, ELH should succeed best in subareas if the approach and the resulting competition of methods is made possible on the basis of a framework of EU law. It is unlikely to be easy to convince German dogmatists to abandon their own legal education for the purpose of pure case law without presenting a Union system. This is something that could be worked on, although it cannot be ruled out that case law could eventually gain more influence than the doctrine used in civil law. However, such a 'change of model' poses the danger that the importance of case law after Brexit could at least decline for relations with the United Kingdom (see above V.). The special position of the ECJ's case law is thus not harmless, although in practice, it holds paramount importance before the dogmatic penetration of Union $\operatorname{law}^{70}$ and national implementations (at

67 See Armin von Bogdandy, 'Deutsche Rechtswissenschaft im europäischen Rechtsraum', JZ 66 (2011), 1-6 (4); Wolfgang Kahl, 'Dogmatik im EU-Recht', AöR 144 (2019), 159-207 (194); Uwe Kischel, 'Diskursvergleich im internationalen und nationalen Recht', VVDStRL 17 (2018), 285-326 (300-302). Admittedly, there are some differences between French «doctrine» and German 'dogmatics' as well as the pragmatic British treatment of case law.

68 See for example already Holger Fleischer, 'Europäische Methodenlehre: Stand und Perspektiven', RabelsZ 75 (2011), 700-729; for further insights see Karl Riesenhuber (ed.), European Legal Methodology (Cambridge: Intersentia 2017); revealing for private law Stefan Grundmann, Hans Micklitz and Moritz Renner, New Private Law Theory A Pluralist Approach (Cambridge: Cambridge University Press 2021).

69 Alexander Somek, Rechtsheorie (Hamburg: Junius 2017), 32.

$70 \mathrm{Kahl}$ (n. 67), 160 (n. 250) for example, sees a particular need for work on terms, the elaboration of principles, and the classification and evaluation of casuistry. 
least for corporate mobilities). From the point of view of national and supranational doctrine, legal harmonisation seems to be not only a cultural obstacle but also a de facto counterpart to the hitherto superior case law in the relevant areas of European law, such as FoE. What may be somewhat surprising here is that a strong bundle of common law nations for whom the case law approach is outstanding anyway does not characterise the EU itself.

\section{Expansion of the National Discourse through Key Player}

The complex key player structure outlined here, for only one area, is likely to have the potential for national integration and implementation of legal harmonisation, in addition to the perspective of democratic legitimation. Such self-reflection could, in the future, also draw attention to interdisciplinary aspects of socio-legal discourses. ${ }^{71}$ Although the above effects and basic requirements of the ELH were discussed thematically and to some extent dogmatically, the factual side must also be considered in a structure as complex as the EU field.

When complaining about 'too many requirements' from the EU, one rarely has an overview of the entire range of driving forces, all of whom have decided on these legal requirements. For example, in jurisprudence and practice, the work of the JURI (see II. 2.) should be given more attention because this is where the directive projects are put together in detail. However, respective rapporteurs, the organisation within the Commission, etc. should also be mentioned. Some sympathy should be developed for the background of the legislative process by using key players to this end. The exercise should also make it clear when European law, European policy, and the individual areas of law are at cross purposes at the national level or, vice versa, when there is a consensus among some Member States. However, in that case greater transparency is required of the key Member States that have supported, particularly campaigned for, directive projects. Transparency ${ }^{72}$ ensures that the standards for shaping the law are understood. With this, Member States could accordingly achieve a better legal understanding of each other. At the same time, the field of law outlined here must also stand pars pro toto for other areas of law, whereby in the following it will primarily be a matter of sounding out the limits of the politics for lawyers working in the Member States.

71 See already for the EU Law with sociological stance Vauchez (n. 60), 128.

72 See already Art. 15 TFEU. 
The key player presentation also shows strong national influences. Experts, the organisation within the JURI, etc. have a national background that they take into the legislative process. However, this does not have to be a negative aspect considering the feedback from the bottom (Member State level) to the top (European level). If more information about this is provided nationally and more research is carried out, then legal harmonisation will be approved, at least in the states concerned. The question is whether a Member State simply wants to transfer the domestic legal status to the European legislative procedure or rather whether it wants to implement special topics for the first time, particularly at the European level. However, the latter, lacks its own litmus test which has already been tried out in its own Member States. Concepts that have not yet been self-tested are, therefore, unlikely to be presented first for European legislation. It is therefore more likely that particularly strong national legal developments are attempted to be taken to a higher European level. Does this mean that it is time for the full harmonisation of individual areas of law (European codes) as long as there is a majority and a mix of different legal cultures represented? What seems to be simply lacking - regardless of finding a majority - is a legal-theoretical support. An inter-systemic theory of law would have to be applied, which complements traditional thinking within a legal system with thinking between legal systems. Today, it is hardly possible to affirm this (see above VI. 3.), and despite all the similarities that some rights have (e.g. German to Austrian [company] law), there remain a number of fundamental systemic differences. There is nothing judgemental or negative to be added to this: it is simply a cultural question for the full harmonisation of which the idea of European law does not seem to be ready, not for some time yet. The national discourse should therefore be strengthened instead of being abolished. In summary, the national cultural discourse in various European fields of law still seems too strong and peculiar, whereas the European discourse seems too weak and not methodologically strengthened. It can therefore hardly be a question of a full ELH but rather of individual steps towards or away from it. It can also be a question about statements of respective national and European key players.

Finally, the ECJ must be mentioned in its special role, at least in the example of FoE. In contrast to the Commission, the ECJ must decide on the submissions of national courts in a timely manner and cannot evade this obligation either by setting up expert groups or questioning the public. However, the Court never endeavoured to play the role of the 'engine of integration', which was originally intended for the Commission. The ECJ was forced to play it because some accents had shifted during the EU standardisation process. The initiatives came from private bodies that brought certain cross-border cases to the ECJ through the medium of na- 
tional courts. However, this does not change the fact that the ECJ itself can take on the major role and pronounce ground-breaking judgements (see here on FoE). Legal practitioners, public authorities, and national courts must attempt to interpret and apply national legal rules in light of the case law of the ECJ. All this is fraught with uncertainties and in some cases does not fit into the national legal concept at all. Accordingly, if the ECJ and - before that - the Advocates-General (!) given this pioneering role, greater confidence in this institution should be developed. Of course, this begins with the allocation of positions, in the sense that within the Member States the judicial appointment ${ }^{73}$ to the ECJ becomes even more important, including the media. However, one can also take the position that the judiciary should not have such a de facto strong legislative role, as there is no political feedback. Indeed, the example of corporate mobility shows how the ECJ almost singlehandedly dominates the issue at the European level. In view of the Union's specific concept of democracy (Art. 2 TEU), this particularly unconventional path laid by the ECJ would need special justification ${ }^{74}$. However, it has little to do with dogmatism or methodology, but it focuses more on the basic European political understanding and the legal cultures and peculiarities arising from the Member States. These aspects can certainly be taken into account more aptly in the legislative process than in case law.

\section{Coda}

Pursuing legal harmonisation in Europe in all areas of law would be a mammoth task for an individual; yet, the task that would require a whole team to accomplish it could be worthwhile. Regarding FoE, it should be shown that ELH has been taking shape for many years and that new requirements are constantly being created 'from above'. This leads to the development of a separate legal field, a separate system that must be investigated. Legal subjects receive a kind of content upgrade. Here, key players could be identified, the role of the ECJ could be emphasised and topics of Europeani-

73 On a critical view of a non-transparent procedure, for example, Volker Epping, 'Die Demokratische Legitimation der Dritten Gewalt der Europäischen Gemeinschaft', Der Staat 36 (1997), 349-380 (361-362); Peter M. Huber, in: Rudolf Streinz (ed.), EUV/AEUV (3rd edn, Munich: C. H. Beck 2018), TFEU, Art. 253 para. 14; see from a German view for the selection of the judges, however, subdivision Europe, Department Europe, German Bundestag, state of affairs, PE 6 - 3000 - 150/18 [2018].

74 Et ceterum censeo, the superior position of the ECJ was presented here for the ELH on FoE from a subjectively felt and pointillist observation. This does not mean that it has to be that right and that it is also beneficial in the future to have the ECJ take over the leadership on questions of European private law. 
sation could be briefly pursued. Over time, a logical development could be initiated by the ECJ for corporate mobility based on FoE, in which the monopoly position of this institution - not political in itself - is remarkable. Full harmonisation is probably not yet on the way in terms of integrating legal culture and is hardly feasible in practice. The idea of competition would be completely lost. On the other hand, stronger feedback at the national level and more leeway in implementation should be feasible and provide legal fields with the opportunity to set thematic priorities at the national level instead of simply 'implementing' and 'reacting'. Soft or principle-based harmonisation requirements would possibly give greater expression to the diversity of legal areas. At best, this could also result in synergies between national and European harmonisation levels. However, the deeper involvement of persons and institutions as well as the consideration of national doctrine must not be overrun by an ELH that does not consider these parameters. The latter is concerned with the ECJ's prominent approach and regulation. In other words, what is needed according to this study is a balanced consideration of national, dogmatic-cultural, and sociological factors. Due to an uncritically considered move to a more or even fully harmonised system and ground-breaking ECJ rulings, which cannot always be coordinated with national doctrine and remain a topic of democratic policy at least, the goal may not be achieved despite well-intentioned attempts to that end. 